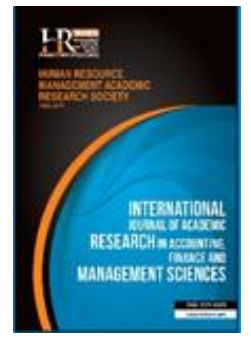

International Journal of Academic Research in Accounting, Finance and Management Sciences

Vol. 9, No.3, July 2019, pp. 150-159

E-ISSN: 2225-8329, P-ISSN: 2308-0337

(C) 2019 HRMARS

www.hrmars.com

To cite this article: Ahmad, N. F. G., Zamil, N.A.M., Basiruddin, R., Saruchi, S.A. (2019). The Ownership Structure,

Capital and Bank Lending in Times of Crisis: Islamic Banks Versus Conventional Banks, International Journal of

Academic Research in Accounting, Finance and Management Sciences 9 (3): 150-159

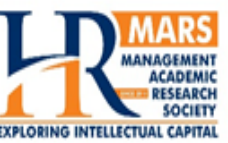

\title{
The Ownership Structure, Capital and Bank Lending in Times of Crisis: Islamic Banks versus Conventional Banks
}

\author{
Nor Faezah Ghazi Ahmad ${ }^{1}$, Nor Aiza Mohd Zamil2, Rohaida Basiruddin ${ }^{3}$, \\ Sarah Athirah Saruchi ${ }^{4}$ \\ 1,2,3,4Azman Hashim International Business School, Universiti Teknologi Malaysia, Kuala Lumpur, \\ E-mail: norfaezahga@gmail.com (Corresponding author)
}

\begin{abstract}
This study empirically investigates the relationship between ownership structure, capital, and bank lending for Islamic and conventional banks during the financial crisis of 2008 to 2009. Using 118 banks from 19 countries over the global financial crisis, the study examines whether the relationship varied with the ownership structure and capital quality on bank lending behaviour. The authors found that governmentowned Islamic banks had a higher loan growth rate than conventional banks during the crisis. The increased lending of the government-owned banks was correlated with high-quality capital and more positive GDP and inflation over the duration of the crisis. The evidence supported the notion that the government-owned banks had a significantly positive effect on the lending growth in Islamic banks after the banks retained sufficient capital. High capital quality can help Islamic banks to survive during a financial crisis and to channel credit in the real market. This study contributes to the proof support that the Islamic banking system can be beneficial for financial and economic stability, especially during a financial crisis.

Key words Government-Owned Bank; Foreign-Owned Bank, Islamic Bank; Conventional Bank, Tier1 Capital, Tier2 Capital

Received: 15 Sep $2019 \quad$ (C) The Authors 2019

Revised: 22 Sep 2019 Published by Human Resource Management Academic Research Society (www.hrmars.com)

Accepted: $\quad 30$ Sep 2019 This article is published under the Creative Commons Attribution (CC BY 4.0) license. Anyone may Published Online: $\quad 03$ Oct 2019 reproduce, distribute, translate and create derivative works of this article (for both commercial and non-commercial purposes), subject to full attribution to the original publication and authors. The full terms of this license may be seen at: http://creativecommons.org/licences/by/4.0/legalcode
\end{abstract}

\section{Introduction}

The financial globalisation that has taken place has opened up an opportunity for the banking sector of the country to allow the entry of foreign banks and to undertake a large range of banking activities. The inclusion of these foreign banks can support the host countries to access additional capital, improve skills and technology and further enhance investment and national development (Cull and Martínez Pería, 2013; Cull et al., 2017). Nevertheless, the presence of these foreign banks provides competition for the domestic banks in order to attract the interest of customers and to enhance the investment profitability and reputation of the domestic banks. The global liquidity crisis that led to the collapse of Lehman in 2008 also raised concerns about the effectiveness of allowing the entry of foreign banks where it has led to a global financial crisis. At that time, banks had to reduce their international transactions, particularly for emerging market countries by $80 \%$ from $\$ 500$ billion to $\$ 100$ billion (Dekle and Lee, 2015). The profit in emerging market countries was adversely affected by the reduction of this activity as well as the adverse effects on domestic assets and financial systems. However, the existence of domestic banks controlled by the government, that is government-owned banks, played a significant part in ensuring economic stability. Still, 
after the entry of foreign banks, the ownership of the assets of the government-owned banks declined mainly in developing countries due to the highly stable and efficient service provided by foreign banks. Therefore, the question arises as to how far the government-owned banks would be able to compete and survive to strengthen the economy of the country and whether capital injection by the government enables the government-owned banks to continue to be sustainable during a financial crisis.

Furthermore, after the recent crisis period, the Basel Committee highlighted the critical importance of sufficient capital buffers. Therefore, numerous literature studies have examined the impact of bank capital on lending to promote awareness of this issue (Kim and Sohn, 2017; Košak et al., 2015; Louhichi and Boujelbene, 2017; Schwert, 2018). Some of the scholars focused on the factors that slowed credit growth during the financial shock. For example research (Behn et al., 2016; Schwert, 2018) highlighted the effect of capital quality on bank lending and (Košak et al., 2015) indicated low bank capital quality weakened the bank lending growth during the financial crisis. Similarly, Louhichi and Boujelbene (2017) addressed the view that banks significantly reduced their lending when funding deposit quality was not available.

This study empirically investigates the relationship between ownership structure, bank capital and lending for Islamic versus conventional banks during the 2008 to 2009 global financial crisis. To the knowledge of the authors, there is a lack of research analysing this relationship and in order to examine this topic, data was selected from 118 sample banks from Islamic and conventional banks in 19 countries that have dual banking systems. This study took into account the global financial crisis as an important factor because it not only affected the largest US Lehman bank, but the crisis also affected financial institutions worldwide. Therefore, this study looks in more detailed to compare the lending behaviour in commercial banks, particularly between the Islamic banks and conventional banks during such a critical time. In general, this study attempts to determine how the ownership structure affected the bank lending behaviour, and was there any effect caused by the capital structure on the bank lending behaviour for Islamic banks and conventional banks during the financial crisis.

The main result of this study shows that Islamic banks had high capital quality at Tier 1 as compared to the conventional banks whereby this proved that Tier 1 capital could act as a buffer for the banks to stand stable during the financial crisis. Furthermore, studies have shown that Islamic banks have a stronger financial system than conventional banks due to being interest-free as applied in accordance with the principles of Islamic law in the operation of the Islamic banks. The findings show that the governmentowned banks as Islamic banks had good capital quality compared to the conventional banks during the crisis affecting credit supply in the market.

This study contributes to the existing literature with respect to the comparison of bank lending behaviour during a financial shock for different types of banking system, namely Islamic versus conventional. Previous studies have consistently agreed that the crisis was a reason why lending/financing turned out to be minimal and it became expensive (Cohen and Scatigna, 2016; Ibrahim and Rizvi, 2018). This scenario led to a shortage of credit supply in the market and this adversely affected overall economic growth. Therefore, it is important for banks to have high-quality capital to absorb any losses during a crisis. The contribution of this study to the body of literature is to examine the association between ownership structure and capital quality on the impact of bank lending behaviour for two types of banking systems during a financial crisis.

\section{Literature review and Hypotheses Testing}

\subsection{Ownership structure and credit supply}

Lending is one of the alternative sources for deficit units (especially for small and medium-sized firms) that have financial problems to cover any shortages. Credit supply is very important not only for the firms but also, it is important for the overall economic development of the country (Sanfilippo-Azofra et al., 2017). Therefore, lending provided by banks whether government-owned or foreign-owned, is essential to address the problem of insufficient credit in the market as well as to help develop the national economy.

Ownership structure refers to the right to control something and to determine the direction of a company (Jensen and Meckling, 1976). In the context of banking institutions, most researchers classify the ownership structure into two, namely domestic banks and foreign banks (Adams-Kane et al., 2017; Bassett et al., 2017; Cull et al., 2017; Lee and Hsieh, 2014; Lin et al., 2016; Shaban and James, 2018). Traditionally, a 
domestic bank will be controlled and the ownership is shared by the government with a minimum ownership of 50 percent and possibly more, and referred to as a government-owned bank. On the other hand, a foreign bank refers to a 50 percent foreign investment share and is named as a foreign-owned bank (Cull and Martínez Pería, 2013). Therefore, the ownership structure depends on the largest shareholding of a party, whether government ownership or foreign ownership to determine the governance of the bank. Each of these banks has a distinctive role in which a government-owned bank has a responsibility to promote economic stability by providing and channelling credit to the real economy, especially during a crisis. Most of the small banks will reduce the credit supply to protect the banks from a shortage of liquidity. Thus, government-owned banks channel financial surplus to deficit units, while foreign-owned banks play a role in providing capital, skills and innovation for host countries (Brei and Schclarek, 2013, 2015; Coleman and Feler, 2015). Typically, the entry of a foreign bank into a country is made by a sound financial bank. Therefore, this bank will provide sufficient capital and use advanced technology to compete with domestic banks and improve the efficiency of the banking sector. Therefore, foreign-owned banks play an important role especially in developing countries (Linda, 2004). Hence, the ownership structure of the bank is important to ensure sufficient credit supply in the market and the role of each bank can be used effectively especially during a financial crisis.

\subsection{Hypotheses formulation}

Since the start of the global financial crisis (GFC), many literature studies have investigated the characteristics of banks to determine how banks can be protected from experiencing drastic financial shock. One of the interesting studies in the literature highlighted the objectives and principles of lending bank behaviour. However, each of the banks has different principles. A government-owned bank, for example, serves to safeguard the social-welfare of the country and is not strictly profit-orientated. As stated by Chen et al., (2016), a government-owned bank has strong liquidity as it is indirectly guaranteed by the government. Therefore, such a bank would be able to supply bank lending during a GFC as it has very strong bank liquidity although the activity would not bring much profit to the bank. As compared to the profit-orientated nature of foreign banks, typically such banks tended to decrease the credit supply during a GFC to protect the banks from a lack of liquidity. To safeguard the interests of the stakeholders and to maintain a long-term relationship with the shareholders, the foreign banks take action to reduce international exposure to prevent the banks suffering any losses. Zeitun et al. (2017) pointed out that the financial crisis reduced the supply of financial resources as it restricted firms from borrowing. Jiménez, Ongena et al. (2012) highlighted that during a crisis, banks cut the credit supply. This is especially true of banks that have low capital and liquidity. Kick et al. (2018); Temesvary and Banai (2017) showed that banks with a lower capital to asset ratio, a high non-performing loan ratio and a lack of emergency liquidity tend to lower the lending growth. In addition, Popov and Udell (2012) documented that firms have been affected that attempted to get access to credit from banks that did not have steady capital, especially subsidiary banks. Therefore, the capitalisation, liquidity, and profitability condition have a strong effect on lending growth particularly during a financial crisis.

This study aims to test the significance of the ownership structure, namely government-owned banks and foreign-owned banks as well as bank capital on bank lending/financing behaviour during a GFC. Therefore, to accomplish the objectives of the study, the following hypotheses are enunciated:

H1: Islamic banks had higher Tier 1 capital than conventional banks during the global financial crisis 2008 to 2009.

H2: Conventional banks had higher Tier 2 capital than Islamic banks during the global financial crisis 2008 to 2009.

H3: Islamic banks had higher loan growth than conventional banks during the global financial crisis 2008 to 2009.

H4: The increased Tier 1 capital of government-owned banks during the crisis period was more likely to improve the financing growth of Islamic banks than the conventional banks. 


\section{Methodology of research}

An empirical model was formed to examine the relationship between the different ownership structures with respect to bank lending behaviour during the GFC. The authors implemented the ownership structure as independent variables. The empirical model is stated below:

$$
\Delta \mathrm{GL}=\beta \_0+\beta \_1 \mathrm{OS}+\beta \_2 \mathrm{BC}+\beta \_3 \mathrm{IB}+\beta \_4 \mathrm{GFC}+\beta \_5(\mathrm{IB} \times \mathrm{GFC})+\varnothing \text { Control }+\mu+\varepsilon
$$

Based on the model above, $\triangle \mathrm{GL}$ refers to the growth rate of the lending growth of the bank that represents bank behaviour. OS is the ownership structure (government-owned bank or foreign-owned bank). BC is the bank capital (Tier1 or Tier2), while IB refers to an Islamic bank dummy. GFC is the global financial crisis dummy. Control is the vector of the controlled variable for the bank-specific and macroeconomic variable, $\mu$ is the bank-specific effect, and $\varepsilon$ is the standard error term. The common bankspecific variable across the bank lending behaviour is bank size (InTA), bank risk (NPL), profitability (ROAA) and tangibility of bank asset (FATA). The macroeconomic variable consists of the real GDP growth and inflation rate (INF).

Two-step dynamic panel model estimation called the general method of moment (GMM) was created to address endogenous problems as proposed by Arellano and Bover (1995) and Blundell \& Bond (1998). This is employed by the (Windmeijer, 2005) correction for downward bias in standard errors and it is often associated with dynamic models. For testing autocorrelation, the authors performed the ArellanoBond test, $A R(2)$ is insignificant indicate that no autocorrelation while the Hensen test was executed to test the instrument validity to ensure the consistency of the estimation.

\subsection{Variable definition}

The bank lending/credit growth rate of Islamic banks in this study was measured by the logarithmic difference of the gross loan $(\Delta \mathrm{GL})$ of the bank. This measure has been used in many empirical studies (García-Posada and Marchetti, 2016; Ibrahim, 2016; Ibrahim and Rizvi, 2018; Louhichi and Boujelbene, 2017). The credit growth rate was measured by the gross loans of the bank. The ownership structure refers to the independent variable. Two types of ownership structure were implemented as a government-owned bank or a foreign-owned bank. These types of bank were determined by the percentage ownership which should be at least 50 percent or more owned by the government for a government-owned bank or shared by a foreign investor for the foreign-owned bank. As for bank capital, the authors computed Tier1 and Tier 2 to measure the quality of the capital of the bank to absorb losses.

Consistent with previous studies, this research incorporated a control variable to investigate the behaviour of bank lending during the GFC. Two control variables were included as a bank-specific variable and also a macroeconomic variable. The study lists four bank-specific variables to test the hypothesis, namely fixed asset to total assets ratio (FATA), bank size (InTA), profitability (ROAA), and credit risk (NPL). The FATA variable is explanatory to control the financial activities of the bank by measuring the cost of nonavailabilities of earning assets in the balance sheet. Studies show that a high FATA will reduce the liquidity and stability of the bank (Louhichi and Boujelbene, 2017). Therefore, this study attempts to develop a negative relationship concerning the growth of lending activities. There is an argument on the topic of "too big to fail" during a global financial crisis. Therefore, the authors controlled the bank size (InTA) using the natural log of total assets. However, Kashyap and Stein (1994) found that small banks were easily affected during the GFC while large and multinational banks were found to have sound and financial stability. Finally, following (Bermpei et al., 2018; Ibrahim, 2019), the explanatory variables included real GDP growth and inflation as a measure control for the loan demand to capture macroeconomic cycles and uncertainty. High GDP and low INF could reduce the weakness and increase the financial strength of the bank. Consequently, positive relationships are predicted to remain to be kept for GDP while there is expected to be a negative relationship associated with INF. 


\section{Data and estimation results}

\subsection{Data descriptions}

The relevant study only considered data relating to cross-country samples obtained for countries providing Islamic and conventional banking services. The final drawn sample consisted of 59 Islamic banks operating in 19 countries. This included the Middle-East, Northern Europe, and Asian countries, namely: Bangladesh, Bahrain, Brunei, Egypt, Indonesia, Jordan, Kuwait, Lebanon, Malaysia, Pakistan, Palestine, Qatar, Saudi Arabia, South Africa, Thailand, Turkey, Tunisia, United Arab Emirates, and the United Kingdom.

Table 1. Summary of variables, descriptions, and sources

\begin{tabular}{|c|c|c|c|}
\hline Classification & Variable & Description & Sources \\
\hline Lending behaviour & $\Delta \mathrm{GL}$ & The growth of gross loan & Bankscope and annual report \\
\hline \multirow[t]{2}{*}{ Ownership structure } & GOB & At least $50 \%$ government share & Bankscope and annual report \\
\hline & FOB & At least $50 \%$ private or foreign investors share & Bankscope and annual report \\
\hline \multirow[t]{2}{*}{ Capital structure } & Tier1 & Tier 1 capital ratio & Bankscope and annual report \\
\hline & Tier2 & Tier 2 capital ratio & Bankscope and annual report \\
\hline \multirow{4}{*}{$\begin{array}{l}\text { Control variables } \\
\text { Bank- specific }\end{array}$} & $\operatorname{lnTA}$ & The logarithm of total assets & Bankscope and annual report \\
\hline & ROA & Profit: Return on assets & Author calculation \\
\hline & FATA & $\begin{array}{l}\text { The tangibility of bank assets: the ratio of fixed } \\
\text { assets to total assets }\end{array}$ & Bankscope and annual report \\
\hline & NPL & $\begin{array}{l}\text { Credit risk: the ratio of non-performing loans to } \\
\text { gross loan }\end{array}$ & Bankscope and annual report \\
\hline \multirow{2}{*}{$\begin{array}{l}\text { Macroeconomic } \\
\text { variable }\end{array}$} & $\Delta \mathrm{GDP}$ & The growth rate of real gross domestic product & World Bank (2017) \\
\hline & INF & Inflation rate & World Bank (2017) \\
\hline
\end{tabular}

Data obtained from audited annual bank reports was a primary source while data was also extracted from the Bankscope database. In addition, the main source of information of macroeconomic data was obtained from the World Bank. Descriptive and detailed definitions are illustrated in Table 1.

Table 2 displays the descriptive statistics of the variables as capitalisation, as well as Tier 1 independent variables along with $\Delta \mathrm{GL}$ as the dependent variable and two main control variables which are the bank-specific variables and macroeconomic. Based on Table 2, the mean value of $\Delta G L$ is 18.415 while the Tier 1 capital is 16.070 .

Regarding the capital structure, Table 2 shows the annual mean of credit growth for Islamic banks which emerged to have significantly higher (19.94\%) growth than conventional banks (18.41 \%). Furthermore, bank capital especially Tier 1 for Islamic banks is significantly higher (16.18\%) than the counterparty (16.07 \%). However, Islamic banks appear to have a lower rate for Tier 2 capital. As for the ownership structure, the government-owned banks of the Islamic banks stipulated the average value of $\mathrm{GOB}$ is slightly lower than the conventional banks.

However, the mean value of FOB in the Islamic banks is higher than for the conventional banks. For the bank-specific variables, bank credit risk, which is NPL in conventional banks (4.30\%) is higher than for Islamic banks (2.81\%) during the global financial crisis. The result is consistent with previous studies recorded by (Kabir et al., 2015; Louhichi and Boujelbene, 2016, 2017) in which the default loans affected the financial stability of the banks. In addition, for the tangible asset FATA, Islamic banks appeared to be riskier than conventional banks where they recorded higher (1.72\%) than the counterparty at only (1.59\%). However, these differences can be seen from the point of view of the size of the bank for both types where the size of conventional banks is larger than the Islamic banks. The result is precise that the operating system of the Islamic banks is still at an important stage of comprehensive evolution as compared to conventional banks in most sample countries.

Table 3 illustrates the correlation coefficient between the tested variables. The result clearly shows that credit growth $\triangle \mathrm{GL}$ has a positive correlation with Tier1, GOB, ROAA, GDP, INF, and crisis. This indicates that the quality of capital, the full effect of bank ownership, profitability and economic stability affected 
credit growth during the financial crisis. However, for the foreign-owned bank entry FOB, the tangibility of the bank assets FATA, size of small banks InTA and holding many bad loans NPL could reduce the credit growth of the banks.

To investigate the credit growth behaviour for Islamic banks and conventional banks during the GFC, combined and separate samples have been implemented. The results are listed in Table 4 . As a result of the analysis, the authors found that the outcome was quite puzzling. Using the combined data, the consequence shows a significant relationship in the credit growth between Islamic banks and conventional banks during the financial crisis. However, when inspecting the separate data, the authors found conventional banks appeared to have no significance in terms of the credit growth while Islamic banks were constantly significant. For bank capital, core capital Tier 1 was significant with credit growth on combined data. However, when the authors estimated the equation separately for both types of bank, the authors found conventional banks indicated no significance but this capital was a very significant effect for Islamic banks, especially during the financial crisis and there was a significant reduction in credit growth in the normal period although only at $10 \%$ significance level. This study appears to be in line with the previous literature (Košak et al., 2015; Louhichi and Boujelbene, 2017). However, Tier 2 showed an insignificant relationship with credit growth for Islamic banks and conventional banks. In practice, banks with a highquality Tier1 capital will be less sensitive in terms of credit and liquidity risk as this would be able to protect banks from any potential losses. From this result, the authors drew the conclusion that the financing growth of Islamic banks during a financial shock tends to be influenced by the high-quality of bank capital.

As for ownership structure behaviour, the authors found that the behaviour of the governmentowned banks with respect to financing growth was higher for Islamic banks during the crisis period at 23.41 $\%$ as compared to $10.48 \%$ during the normal period. Foreign-owned banks in Islamic banks had to cut international exposure during the critical year. Furthermore, the situation was different from conventional banks where the behaviour of foreign-owned banks with respect to credit growth decreased during the financial crisis. In contrast, during the crisis, the credit growth behaviour of foreign-owned banks in Islamic banks recorded higher by $20.18 \%$. Therefore, the government-owned banks in Islamic banks have proven to be more stable in that the banks have enough liquidity and capital to provide credit support during a global financial crisis.

Table 2. Descriptive Statistics of Variables

\begin{tabular}{lccccccccc}
\hline & \multicolumn{3}{c}{ All sample banks } & \multicolumn{3}{c}{ Conventional banks } & \multicolumn{2}{c}{ Islamic banks } \\
\hline Variable & Obs & Mean & Std. Dev. & Obs & Mean & Std. Dev. & Obs & Mean & Std. Dev. \\
\hline$\Delta$ GL & 1050 & 18.415 & 21.774 & 527 & 16.899 & 18.236 & 523 & 19.942 & 24.758 \\
Tier1 & 1155 & 16.070 & 7.338 & 591 & 15.957 & 7.725 & 564 & 16.189 & 6.914 \\
Tier2 & 1043 & 2.075 & 1.980 & 537 & 2.219 & 1.870 & 506 & 1.922 & 2.082 \\
GOB & 1416 & 0.788 & 0.409 & 708 & 0.796 & 0.403 & 708 & 0.780 & 0.415 \\
FOB & 1416 & 0.212 & 0.409 & 708 & 0.204 & 0.403 & 708 & 0.220 & 0.415 \\
ROAA & 1222 & 1.569 & 2.698 & 623 & 1.693 & 2.297 & 599 & 1.440 & 3.056 \\
FATA & 1148 & 1.591 & 2.472 & 594 & 1.469 & 1.601 & 554 & 1.722 & 3.146 \\
NPL & 899 & 4.305 & 5.865 & 515 & 5.419 & 6.392 & 384 & 2.810 & 4.682 \\
InTA & 1257 & 14.991 & 1.553 & 646 & 15.123 & 1.513 & 611 & 14.852 & 1.584 \\
GDP & 1406 & 4.374 & 3.950 & 704 & 4.376 & 3.952 & 704 & 4.371 & 3.951 \\
INF & 1410 & 4.835 & 4.128 & 705 & 4.852 & 4.182 & 705 & 4.818 & 4.076 \\
Crisis & 1416 & 0.168 & 0.374 & 708 & 0.170 & 0.376 & 708 & 0.167 & 0.373 \\
\hline
\end{tabular}


Table 3. Correlation matrix

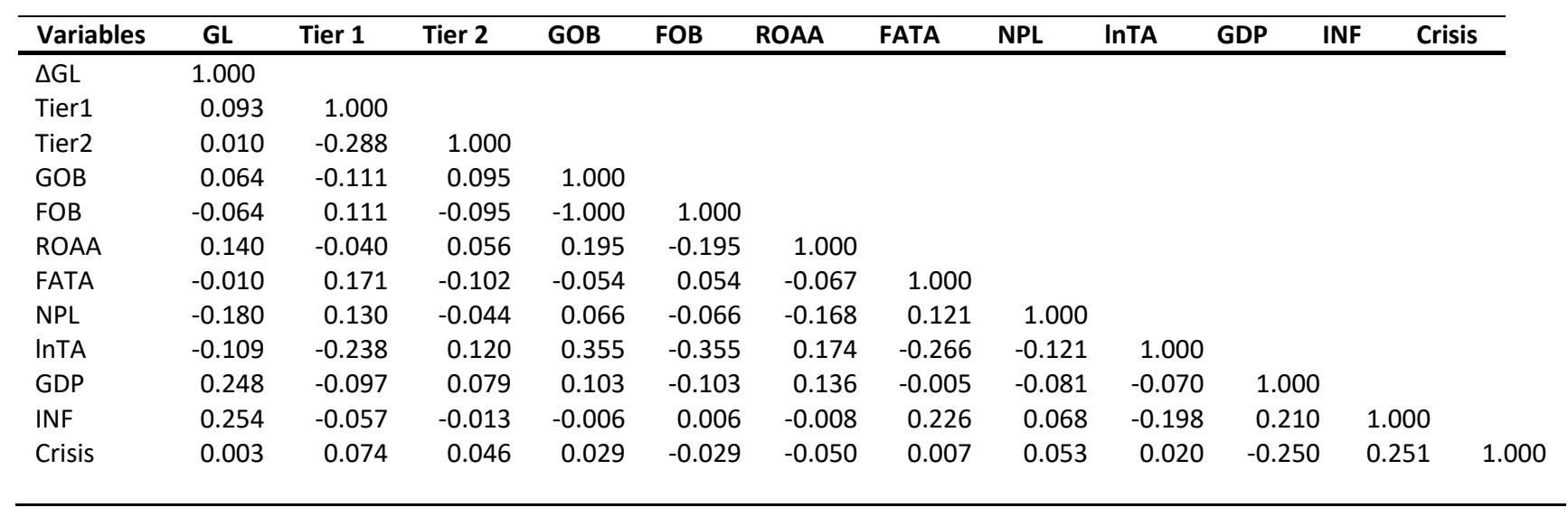

Table 4. Bank lending growth- All banks and separate samples

\begin{tabular}{|c|c|c|c|}
\hline & All sample banks & Conventional banks & Islamic banks \\
\hline \multirow{2}{*}{$\Delta \mathrm{GL}$} & $0.423^{* * *}$ & 0.240 & $0.480 * * *$ \\
\hline & $(0.0876)$ & $(0.155)$ & $(0.109)$ \\
\hline \multirow[t]{2}{*}{ Tier1 } & $1.014^{* * *}$ & 0.447 & $1.267 * *$ \\
\hline & $(0.380)$ & $(0.362)$ & $(0.566)$ \\
\hline \multirow[t]{2}{*}{ Tier2 } & -0.230 & 0.240 & 1.901 \\
\hline & $(0.882)$ & $(0.871)$ & $(1.816)$ \\
\hline \multirow[t]{2}{*}{ GOB } & 10.24 & -11.58 & 23.41 \\
\hline & $(19.47)$ & $(19.65)$ & $(32.75)$ \\
\hline \multirow[t]{2}{*}{ FOB } & -10.24 & 11.58 & -23.41 \\
\hline & $(19.47)$ & $(19.65)$ & $(32.75)$ \\
\hline \multirow[t]{2}{*}{ ROAA } & $0.758 * *$ & 0.316 & 0.961 \\
\hline & $(0.318)$ & $(0.793)$ & $(0.887)$ \\
\hline \multirow[t]{2}{*}{ FATA } & $1.172 * *$ & -0.781 & 2.511 \\
\hline & $(0.480)$ & $(1.128)$ & $(2.286)$ \\
\hline \multirow[t]{2}{*}{ NPL } & 1.043 & -0.401 & 0.616 \\
\hline & $(0.982)$ & $(0.382)$ & $(0.770)$ \\
\hline \multirow[t]{2}{*}{$\operatorname{lnTA}$} & 1.025 & -0.589 & 2.758 \\
\hline & $(1.682)$ & $(2.582)$ & (5.209) \\
\hline \multirow[t]{2}{*}{ GDP } & $1.829 * * *$ & $0.977^{* *}$ & $0.181^{*}$ \\
\hline & $(4.089)$ & $(0.342)$ & $(0.737)$ \\
\hline \multirow[t]{2}{*}{ INF } & $0.161^{* *}$ & $1.483 * *$ & $0.680 *$ \\
\hline & $(0.514)$ & $(0.610)$ & $(0.864)$ \\
\hline \multirow[t]{2}{*}{ Crisis } & $-9.636 * *$ & -5.382 & $-17.32 * *$ \\
\hline & $(3.834)$ & $(4.221)$ & (7.339) \\
\hline \multirow[t]{2}{*}{ Constant } & 35.99 & 28.33 & -44.37 \\
\hline & $(55.58)$ & (34.21) & $(77.10)$ \\
\hline Observations $\mathrm{N}$ & 571 & 347 & 224 \\
\hline Hansen & 0.226 & 0.974 & 0.952 \\
\hline $\mathrm{AR}(1)$ & 0.000 & 0.002 & 0.009 \\
\hline$A R(2)$ & 0.099 & 0.107 & 0.836 \\
\hline
\end{tabular}

Notes: This table reports two-step system GMM, which examines the relationship between ownership structure, capital, and lending/financing for Islamic banks and conventional banks during a financial crisis. The sample period is 2008 to 2009 . For the dependent variable, the growth of gross loan $(\triangle \mathrm{GL})$, the independent variable is Tier 1 capital ratio and Tier 2 capital ratio, government-owned bank (GOB), foreign-owned bank (FOB). The bank-specific variable is Return on average assets (ROAA), the tangibility of bank assets is measured by the ratio of fixed assets to total assets (FATA), credit risk is measured by the ratio of nonperforming loans to the gross loans (NPL), and bank size- the logarithm of total assets. The macroeconomic variables are consistent 
with GDP and inflation (INF). Items in parentheses ( ) are robust standard errors, clustered at the bank level. $* * *, * *$ and $*$ represent statistical significance at $1 \%, 5 \%$ and $10 \%$ respectively.

\section{Conclusions}

Although the Islamic bank is still a relatively evolution stage concept, there is rapid development in which Islamic banks can become a stabiliser in the wake of a catastrophic financial crisis. Therefore, this situation has attracted the attention of many researchers. Covering the scope of the study, this paper contributes to the analysis of the comparison of the lending growth behaviour between Islamic banks and conventional banks covering 19 countries for the period 2008 to 2009. The aim of this study is to empirically evaluate the comparison of lending growth behaviour with respect to capital quality and ownership structure during a financial crisis. Bank capital in this study refers to Tier 1 and Tier 2, while ownership structure is classified into the government-owned banks and foreign-owned banks. From the analysis, the finding clearly revealed that high-quality capital affects credit growth behaviour especially when a crisis occurs. There is strong evidence that Tier 1 in Islamic banks has a significant association with financing growth as compared to conventional banks where the equation is estimated separately. However, the Tier 2 capital ratio appears insignificant for both types of bank.

In addition, the ownership structure for Islamic and conventional banks did not show any significance with credit growth. However, the lending growth of government-owned banks for Islamic banks was higher than conventional banks during the crisis. Meanwhile, foreign-owned banks influence lending growth for conventional banks during the normal period.

This study contributes to the literature in two ways. First, it shows that the relationship effect of the ownership structure and bank capital on credit growth is only significant for bank capital in a governmentowned bank in Islamic banks while banks with low capital quality appear to suffer in times of crisis. Second, highlighting the sharp contrast it can be seen that the lending behaviour between Islamic and conventional banks is different. Although the findings show that ownership structure does not have a significant relationship to credit growth, however from this analysis it is evident that the development of financing for Islamic banks owned by the government is higher than for conventional banks during a financial crisis. It can be concluded that the capital owned by the government banks in Islamic banks is better and stronger due to the fundamental principles adopted by Islamic banks i.e. Islamic law whereby Islamic banks adopt the concept of being interest-free versus a conventional bank that adopts the an interest-based concept. Finally, a specific framework is required for each Islamic bank to streamline the same system and reduce the gap between Islamic banks with various systems. Therefore, regulators and policymakers should develop an international principle for deposit insurance.

\section{References}

1. Adams-Kane, J., Caballero, J. A., \& Lim, J. J. (2017). Foreign Bank Behavior during Financial Crises. Journal of Money, Credit and Banking, 49(2-3), 351-392.

2. Arellano, M., \& Bover, O. (1995). Another look at the instrumental variable estimation of errorcomponents models. Journal of Econometrics.

3. Bassett, W., Demiralp, S., \& Lloyd, N. (2017). Government support of banks and bank lending. Journal of Banking and Finance, 0, 1-16.

4. Behn, M., Haselmann, R., \& Wachtel, P. (2016). Procyclical Capital Regulation and Lending. Journal of Finance.

5. Bermpei, T., Kalyvas, A., \& Nguyen, T. C. (2018). Does institutional quality condition the effect of bank regulations and supervision on bank stability? Evidence from emerging and developing economies. International Review of Financial Analysis.

6. Blundell, R., \& Bond, S. (1998). Initial conditions and moment restrictions in dynamic panel data models. Journal of Econometrics.

7. Brei, M., \& Schclarek, A. (2013). Public bank lending in times of crisis. Journal of Financial Stability, 9(4), 820-830.

8. Brei, M., \& Schclarek, A. (2015). A theoretical model of bank lending: Does ownership matter in times of crisis? Journal of Banking and Finance, 50, 298-307. 
9. Chen, Y. S., Chen, Y., Lin, C. Y., \& Sharma, Z. (2016). Is there a bright side to government banks? Evidence from the global financial crisis. Journal of Financial Stability, 26, 128-143.

10.Cohen, B. H., \& Scatigna, M. (2016). Banks and capital requirements: Channels of adjustment. Journal of Banking and Finance.

11.Coleman, N., \& Feler, L. (2015). Bank ownership, lending, and local economic performance during the 2008-2009 financial crisis. Journal of Monetary Economics, 71, 50-66.

12.Cull, R., \& Pería, M. S. (2013). Bank ownership and lending patterns during the 2008-2009 financial crisis: Evidence from latin America and Eastern Europe. Journal of Banking and Finance, 37(12), 4861-4878.

13.Cull, R., Peria, M., \& Verrier, J. (2017). Bank Ownership: Trends and Implications. IMF Working Papers.

14.Dekle, R., \& Lee, M. (2015). Do foreign bank affiliates cut their lending more than the domestic banks in a financial crisis? Journal of International Money and Finance.

15.García-Posada, M., \& Marchetti, M. (2016). The bank lending channel of unconventional monetary policy: The impact of the VLTROs on credit supply in Spain. Economic Modelling, 58, 427-441.

16.Ibrahim, M. (2019). Capital regulation and islamic banking performance: a panel evidence. Buletin Ekonomi Moneter Dan Perbankan.

17.Ibrahim, M. H. (2016). Business cycle and bank lending procyclicality in a dual banking system. Economic Modelling, 55, 127-134.

18.Ibrahim, M. H., \& Rizvi, S. A. R. (2018). Bank lending, deposits and risk-taking in times of crisis: A panel analysis of Islamic and conventional banks. Emerging Markets Review.

19.Jensen, M. C., \& Meckling, W. H. (1976). Theory of the firm: Managerial behavior, agency costs and ownership structure. Journal of Financial Economics, 3(4), 305-360.

20.Jiménez, G., Ongena, S. R. G., Peydro, J.-L., \& Saurina Salas, J. (2012). Credit Supply: Identifying Balance-Sheet Channels with Loan Applications and Granted Loans. SSRN Electronic Journal.

21.Kabir, M. N., Worthington, A., \& Gupta, R. (2015). Comparative credit risk in Islamic and conventional bank. Pacific Basin Finance Journal.

22.Kashyap, A. K., \& Stein, J. C. (1994). Monetary Policy and Bank Lending. Monetary Policy (Vol. ISBN).

23.Kick, T., Koetter, M., \& Storz, M. (2018). Cross-border transmission of emergency liquidity. Journal of Banking and Finance.

24.Kim, D., \& Sohn, W. (2017). The effect of bank capital on lending: Does liquidity matter? Journal of Banking and Finance, 77, 95-107.

25.Košak, M., Li, S., Lončarski, I., \& Marinč, M. (2015). Quality of bank capital and bank lending behavior during the global financial crisis. International Review of Financial Analysis, 37, 168-183.

26.Lee, C. C., \& Hsieh, M. F. (2014). Bank reforms, foreign ownership, and financial stability. Journal of International Money and Finance, 40, 204-224.

27.Lin, K. L., Doan, A. T., \& Doong, S. C. (2016). Changes in ownership structure and bank efficiency in Asian developing countries: The role of financial freedom. International Review of Economics and Finance, $43,19-34$.

28.Linda, G. (2004). Financial-Sector FDI and Host Countries: New and Old Lessons. NBER Working Paper.

29.Louhichi, A., \& Boujelbene, Y. (2016). Credit risk, managerial behaviour and macroeconomic equilibrium within dual banking systems: Interest-free vs. interest-based banking industries. Research in International Business and Finance.

30.Louhichi, A., \& Boujelbene, Y. (2017). Bank capital, lending and financing behaviour of dual banking systems. Journal of Multinational Financial Management, 41(september 2008), 61-79.

31.Popov, A., \& Udell, G. F. (2012). Cross-border banking, credit access, and the financial crisis. Journal of International Economics.

32.Sanfilippo-Azofra, S., Torre-Olmo, B., Cantero-Saiz, M., \& López-Gutiérrez, C. (2017). Financial Development and Banks' Loan Supply in Developing Countries. Journal of Macroeconomics, 55(April 2017), 215-234.

33.Schwert, M. (2018). Bank Capital and Lending Relationships. Journal of Finance. 
34.Shaban, M., \& James, G. A. (2018). The effects of ownership change on bank performance and risk exposure: Evidence from indonesia. Journal of Banking and Finance.

35.Temesvary, J., \& Banai, A. (2017). The drivers of foreign bank lending in Central and Eastern Europe: The roles of parent, subsidiary and host market traits. Journal of International Money and Finance, 79, 157-173.

36.Windmeijer, F. (2005). A finite sample correction for the variance of linear efficient two-step GMM estimators. Journal of Econometrics.

37.Zeitun, R., Temimi, A., \& Mimouni, K. (2017). Do financial crises alter the dynamics of corporate capital structure? Evidence from GCC countries. Quarterly Review of Economics and Finance. 